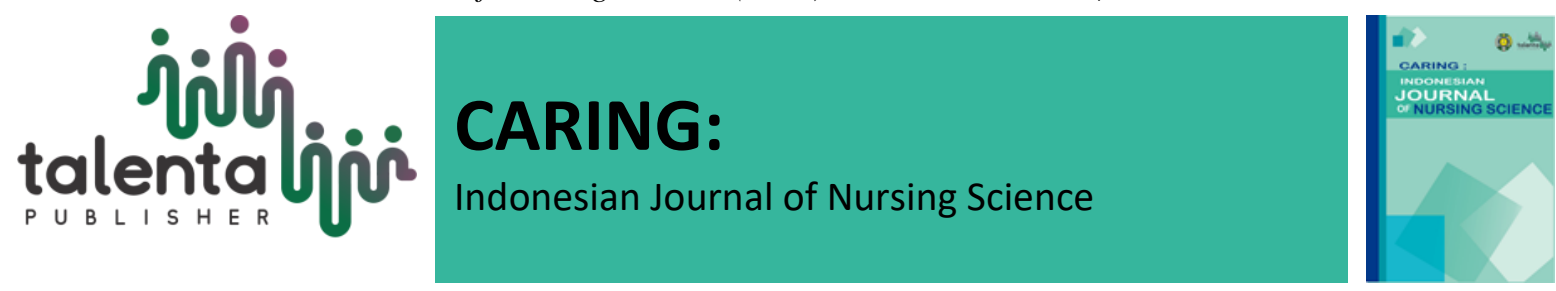

\title{
The Duration of Hemodialysis Treatment and the Adherence of Chronic Kidney Disease Patients in Fluid Intake Limitation: a Relationship
}

\author{
Fitri Mailani ${ }^{1}$, Sri Olta Bakri ${ }^{2}$ \\ ${ }^{1}$ Department of Medical Surgical and Emergency Nursing, Faculty of Nursing, Universitas Andalas, \\ Padang, Sumatera Barat - Indonesia \\ ${ }^{2}$ School of Health Science (STIKes) YPAK Padang, Sumatera Barat - Indonesia
}

\begin{abstract}
Hemodialysis is a routine medical intervention for a patient with chronic kidney disease. The duration of hemodialysis treatment makes the patient's behavior change to be not adherence to the recommended diet, including restrictions on fluid intake. The objective of this research is to determine the Relationship duration of hemodialysis treatment with Adherence to fluid restriction of Chronic Kidney Disease Patients. This cross-sectional study involving 44 respondents, taken by consecutive sampling techniques. Research has been conducted in the hemodialysis room at the Reksodiwiryo hospital in Padang from May-June 2019. Data collection was carried out by looking at medical records and questionnaires regarding fluid intake compliance in patients with chronic kidney disease. The data obtained were analyzed univariate with frequency distribution and bivariate with the Kendall Tau test. The results showed that there were $26(59.1 \%)$ non-adherence patients, and $18(40.9 \%)$ patients were adherence to limiting fluid intake. Old patients were 17 people (38.6\%) and new patients were 27 (61.4\%). The Kendall Tau bivariate test showed that the length of hemodialysis has a significant correlation with adherence fluid restriction $(\mathrm{p}=0.014)$, with a negative correlation $(\mathrm{r}-0.375)$, it's meaning that the longer the hemodialysis, the lower the fluid restriction compliance. It is expected that hemodialysis nurses regularly evaluate the compliance of hemodialysis patients and routinely carry out educational and motivational programs as well as fluid diet counseling at each hemodialysis session.
\end{abstract}

Keywords: compliance, fluid, hemodialysis, restriction

Received 15 June 2020 | Revised 7 June 2020 | Accepted 8 June 2020

\section{Introduction}

Chronic kidney disease and end-stage renal disease are emerging health problems in developing countries that require long term care that is often costly to the patients [1]. Hemodialysis is a therapeutic process that replaces poor functioning of the kidneys with the use of a semipermeable membrane that functions as a nephron to remove metabolic waste products and correct imbalances of liquids and electrolytes in patients who suffer from kidney failure [2]. The hemodialysis process can be conducted two or three times every week and requires three to five

*Corresponding author at: Limau Manis, Kec. Pauh, Kota Padang, Sumatera Barat 25163.

Corresponding email: fitrimailani22@nrs.unand.ac.id

Copyright (C) Published by Talenta Publisher, ISSN: 2580-6769 e-ISSN: 2580-829X

Journal Homepage: https://talenta.usu.ac.id/IJNS 
hours for each session. The results of the Dialysis Consensus state that adequate hemodialysis can be achieved with a total of 10-12 hours per week [3].

For patients with chronic kidney disease, hemodialysis will not change the course of kidney disease and reinstate kidney function. Patients will continue to experience a number of problems and complications [3]. Hemodialysis patients can be categorized as patients with unique conditions because they must spend a considerable amount of time in the hospital, that is, two to three sessions each week to wash their blood, where each session requires four to five hours. This routine must be continued for the remainder of their lives and requires.

The data from the Indonesian Renal Registry (IRR) (2017), indicated that the prevalence of chronic kidney disease in West Sumatra was an increase in the number of active patients undergoing hemodialysis every year. It went up from 25446 to 52835 patients between 2016 and 2017. As well as new hemodialysis patients also increased from 30831 to 77892 patients during the two years period. West Sumatra is one of the provinces in Indonesia which has a high data on kidney failure patients. The data in 2017 revealed the number of active patients undergoing hemodialysis reached $83.3 \%$ of the 12 hospital units that have hemodialysis therapy units throughout West Sumatra [4].

Fluid intake limitation is very important to note in patients undergoing hemodialysis because it can result in rapid weight gain (more than 5\%), edema, rhonchi, swollen eyelids, and shortness of breath caused by excessive fluid volume and uremic symptoms [3]. However, some patients have difficulty in limiting fluid intake since have a poor understanding of correct fluid restriction [5]. A research carried out with the Dialysis Diet and Fluid Non-adherence Questionnaire showed that $76.4 \%$ of patients had difficulty limiting fluid intake [6]. 58.7\% did not comply with fluid restrictions, therefore; they needed to get education and counseling routinely. In several studies stated that there is no standardized method for measuring noncompliance with fluid restriction [7]. More than 50\% of patients undergoing hemodialysis therapy are reported disobey fluid intake restrictions [5]. Fluid restriction is often difficult for patients, especially for those who consume specific drugs such as diuretics which affect the mucous membranes dryness.

Hemodialysis which is done for life will cause burnout. Boredom undergoing therapy that has been done for years has the potential to make the patient's behavior change into disobedience to the recommended diet, including restrictions on fluid intake. The purpose of this study was to determine the relationship between the duration of hemodialysis treatment and adherence to fluid intake limitation among patients with chronic kidney disease. 


\section{Research Methods}

This is a cross-sectional descriptive study and conducted at RS Reksodiwiryo Padang, West Sumatera. The data is collected from 44 patients with Chronic Kidney Disease and selected by consecutive sampling technique. The inclusion criteria are applied such as a compos mentis condition and able to communicate. Data collecting methods were using medical records for finding out the duration of hemodialysis treatment, and the fluid questionnaire to identify the patients' adherence to fluid restriction. The Kendall Tau test brought into the analysis method to identify the finding.

\section{Result and Discussion}

The result of this study showed some significant points such as the respondent's characteristic and the relationship of hemodialysis duration with the patients' adherence in fluid intake limitation. The majority of the respondents were male $(59,1 \%), 41-60$ years old $(45.5 \%)$, middle education (54.5\%), still working (59.1\%), new patients (61.4\%), and non-adherence with fluid intake limitation $(59.1 \%)$. The detail is described in table 1.

Table 1. Personal Characteristics Respondent

\begin{tabular}{|c|c|c|}
\hline Respondent Characteristic & Frequency & Percentage \\
\hline \multicolumn{3}{|l|}{ 1. Gender } \\
\hline Male & 26 & 59.1 \\
\hline Female & 18 & 40.9 \\
\hline \multicolumn{3}{|l|}{ 2. Age (year) } \\
\hline $20-40$ & 16 & 36.4 \\
\hline 41-60 tahun & 20 & 45,5 \\
\hline$>60$ tahun & 8 & 18,2 \\
\hline \multicolumn{3}{|l|}{ 3. Education } \\
\hline Low & 12 & 27.3 \\
\hline Middle & 24 & 54.5 \\
\hline High & 8 & 18.2 \\
\hline \multicolumn{3}{|l|}{ 4. Work } \\
\hline Unemployed & 18 & 40.9 \\
\hline Employed & 26 & 59.1 \\
\hline \multicolumn{3}{|l|}{ 5. Duration of Haemodialysis } \\
\hline Old patients (> 6 month) & 17 & 38.6 \\
\hline New patients ( $\leq 6$ month) & 27 & 61.4 \\
\hline \multicolumn{3}{|c|}{ 6. Adherence to Fluid Intake Limitation } \\
\hline Non-adherence & 26 & 59.1 \\
\hline Adherence & 18 & 40.9 \\
\hline Jumlah & 44 & 100 \\
\hline
\end{tabular}

The bivariate analysis in this study using the Kendall Tau test. Table 2 showed that the duration of hemodialysis treatment has a significant correlation with adherence of fluid intake limitation ( $p$ 0.014), with a negative correlation $(r-0.375)$ it's meaning the longer duration of hemodialysis treatment, the lower the fluid restriction compliance. The table 2 as follows. 
Table 2. Relationship the Duration of Hemodialysis Treatment with Adherence to

Fluid Intake Limitation

\begin{tabular}{|c|c|c|c|c|c|c|c|}
\hline \multirow{3}{*}{$\begin{array}{l}\text { The duration of } \\
\text { Hemodialysis }\end{array}$} & \multicolumn{4}{|c|}{ Adherence to Fluid Intake Limitation } & \multirow[t]{3}{*}{ Total } & \multirow[t]{2}{*}{ p-value } & \multirow[t]{2}{*}{$\boldsymbol{r}$} \\
\hline & \multicolumn{2}{|c|}{ Adherence } & \multicolumn{2}{|c|}{ Non-adherence } & & & \\
\hline & $f$ & $\%$ & $f$ & $\%$ & & 0,014 & $-0,375$ \\
\hline Old Patients & 3 & 17,6 & 14 & 82,4 & 17 & & \\
\hline New Patients & 15 & 55,6 & 12 & 44,4 & 27 & & \\
\hline Total & 18 & & 26 & & & & \\
\hline
\end{tabular}

According to the study showed that $59.1 \%$ patients who undergoing hemodialysis were not adherence to fluid restriction. The finding of this study is similar to the previous research stated that $76.4 \%$ of chronic kidney patients experienced difficult fluid restriction [6]. The difficulty of fluid restriction behavior may result from several factors. For example, Fluid intake is related to physical needs, habits, customs, social rituals, or illness. People drink to ease mouth dryness; to match food consumption or to enjoy the taste or experience of the fluid psychotropic effects. Sodium intake is a major cause of thirsty for patients, Some reports indicated that seasonality can affect fluid consumption. Sodium intake is an important part of the HD patient [8]. The results of the questionnaire analysis of the majority of respondents consume foods that contain flavoring / high sodium, so that thirst increases.

The accumulation of fluids in the body causes the work function of the heart and lungs to be heavy, which results in the physical response of the patient to quickly get tired and tight, physical activity also experiences disturbances both during mild or moderate activities. Limitation of fluid intake will change the lifestyle that patients feel like a disorder. And the recommended diet is not liked by most sufferers so often ignores their diet [9].

Education is an important factor in hemodialysis patients to be able to understand and regulate themselves in limiting eating and drinking. This proves that education has an influence on compliance with fluid intake restrictions for hemodialysis patients, it is expected that the higher the patient's education the more obedient the patient will be in limiting fluid intake [10].

Hemodialysis is a kidney replacement therapy performed by patients with chronic kidney disease which will be carried out for life [2]. The duration of hemodialysis has an effect on adherence to fluid intake restrictions. Each patient needs different time in the level of adherence to the restriction of fluid intake. The longer the patient undergoing hemodialysis, it is expected that the patient will be more obedient and can control the restriction of liquid intake correctly, but it is inversely proportional to what is expected in limiting fluid intake [11]. The longer the patient undergoing hemodialysis therapy the less compliant in limiting fluid intake because the patient has reached the stage of acceptance [12]. 
The study reported that the duration of hemodialysis has a significant correlation with adherence fluid intake limitation $(p 0.014)$, with a negative correlation $(r-0.375)$ it's meaning the longer the hemodialysis, the lower the fluid restriction compliance. The same result with previous studies that patients who are sick for less than one year more adherence to restriction fluid. The longer the illness, the more the risk of decreasing adherence is higher [14]. The same result in South Africa research showed that non-adherence fluid restriction was $10-74 \%$, medication nonadherence ranged from 3 to $80 \%$, and nonadherence to diet was 2-39\% [15].

Research by Nurjannah \& Mailani (2016) showed that One nursing diagnosis that was experienced by all respondents was Activity Intolerance. All of the respondents complained that they were limited in conducting activities because of physical problems related to their disease [16], one of the causes is non-adherence fluid intake limitation. The previous research showed that nursing intervention is beneficial for raising dialysis compliance, providing evidence to strengthen nursing care for chronic kidney disease patients administered with dialysis in daily clinical practice [17].

\section{Conclusion}

The duration of hemodialysis has a significant correlation with adherence fluid intake limitation ( $p$ 0.014), with a negative correlation $(r-0.375)$ it's meaning the longer the duration of hemodialysis, the lower the fluid restriction compliance. Nurses in-unit hemodialysis must give specific interventions such as counseling diet and restriction fluid in each hemodialysis schedule, not only focused on new patients but also old patients. Further research is expected to develop research on appropriate educational methods for HD research fluids and develop complementary research to overcome thirst.

\section{Acknowledgement}

Authors would like to thank the respondents for all valuable data provided in this research.

\section{Conflict of Interest}

There is no conflict of interest in this research result.

\section{REFERENCES}

[1] V. Modi, G. K. and Jha, "The incidence of end-stage renal disease in India: a populationbased study," Kidney Int., vol. 70, no. 12, pp. 2131-3, 2006, doi: 10.1038/sj.ki.5001958.

[2] J. H. Black, J.M., \& Hawks, Medical surgical nursing; clinical management for positive outcome., 8th ed. Philadelphia: W.B. Sounders Company., 2009. 
[3] K. . Smeltzer, S.C., Bare, B.G., Hinkle, J.L., \& Cheever, Textbook of Medical Surgical Nursing, 12th ed. Philadelphia: Lippincott Williams \& Wilkins, 2008.

[4] Indonesia Renal Registry (IRR), report Of Indonesian Renal Registry, 10 th Edition, 10th ed. Jakarta: Perkumpulan Nefrologi Indonesia (Pernefri)., 2017.

[5] Y. T. Barnett, T., Li, Y.T., Pinikahana, J., Si, "Fluid Compliance among Patients Having Hemodialysis: Can An Educational Programme Make A Difference," J. Adv. Nurs., vol. 61, no. 3, pp. 300-306, 2007.

[6] L. Kugler, Garry, Hartigan, M., Carter, B., \& Erlich, "Adherence In Patients On Dialsys: Strategies For Success.," Nephrol. Nurs. Journalnursing Journal, vol. 34, no. 5, pp. 479-487, 2010.

[7] S. Denhaerynck, K., Manhaeve, D., Dobbeles, F., Garzoni, D., Nolte., C., \& De Geest, "Prevalence And Consequences Of Noradherence to Hemodialysis Regimens," Am. J. Crit. Care, vol. 16, no. 3, pp. 222-236, 2007.

[8] N. (Ed. . Thomas, Renal Nursing: Care and Management of People with Kidney Disease. john Wiley \& Sons., 2019.

[9] W. Riyanto, Hubungan antara Penambahan Berat Badan di antara Dua Waktu Hemodialisis (Interdialysis Weight Gain $=I D W G$ ) terhadap Kualitas Hidup Pasien Penyakit Ginjal Kronik yang Menjalani Terapi Hemodialisis, Tesis. Jakarta: Universitas Indonesia, 2011.

[10] Y. Lindbreg, Liu, "Renal Fibrosis: New Insights Into The Pathogenesis And Therapeutics.," Kidney Int., 2010.

[11] A. Sapri, Faktor-Faktor Yang Mempengaruhi Kepatuhan Dalam Mengurangi Asupan Cairan Pada Penderita Gagal Ginjal Kronik yang Menjalani Hemodialisis di RSUP Abdoel Moeloek Bandar Lampung, Skripsi. Yogyakarta: FK UGM, 2008.

[12] S. Nurchayati, "Analisis Faktor-Faktor yang Berhubungan dengan Kualitas Hidup Pasien Penyakit Ginjal Kronik yang Menjalani Hemodialisis," http://repository.usu.ac.id/bitstream/123456789/27561/7/, 2011.

[13] D. C. Anita and D. Novitasari, "Kepatuhan Pembatasan Asupan Cairan Terhadap Lama Menjalani Hemodialisa," J. Kesehat. Masy., vol. 1, no. 1, pp. 104-112, 2017.

[14] L. Kammerer. J., Garry, G., Hartigan, M., Carter, B., \& Erlich, "Adherence In Patients On Dialsys: Strategies For Success," Nephrol. Nurs. Journalnursing J., vol. 34, no. 5, pp. 479-487, 2007.

[15] C. G. Geldine, B. Bhengu, and A. Manwere, "Adherence of adult Chronic Kidney Disease patients with regard to their dialysis, medication, dietary and fluid restriction," Res. J. Heal. Sci., vol. 5, no. 1, p. 3, 2017, doi: 10.4314/rejhs.v5i1.2.

[16] I. Nurjannah and F. Mailani, "The most frequent diagnosis on patients undergoing hemodialysis," Int. J. Res. Med. Sci., vol. 4, no. 10, pp. 4453-4457, 2016, doi: 10.18203/2320-6012.ijrms20163310.

[17] J. Wang et al., "Nursing Intervention on the Compliance of Hemodialysis Patients with End-Stage Renal Disease: A Meta-Analysis," Blood Purif., vol. 45, no. 1-3, pp. 102-109, 2018, doi: 10.1159/000484924. 